\title{
Metaphor as a Strategy of Language Politeness: A Study of the Novel Tetralogy by Ki Padmasusastra
}

\author{
Onok Yayang Pamungkas ${ }^{1,2,}$, Sahid Teguh Widodo ${ }^{3}$, Suyitno $^{4}$, Suwardi \\ Endraswara $^{5}$ \\ ${ }^{1,4}$ Faculty of Teacher Training and Education, Universitas Sebelas Mare, Surakarta, Indonesia \\ ${ }^{2}$ Faculty of Teacher Training and Education, Ma'arif Nahdlatul Ulama University, Kebumen, Indonesia \\ ${ }^{3}$ Faculty of Cultural Sciences, Universitas Sebelas Maret, Surakarta, Indonesia \\ ${ }^{5}$ Faculty of Language and Arts, Yogyakarta State University, Indonesia \\ *Corresponding author. Email: onokyayangpamungkas@gmail.com
}

\begin{abstract}
This research attempts to explain Tetralogy Novel by Ki Padmasusastra (in the future referred to as NTKP) from politeness. This study used qualitative research methods - the data source for the novels by Ki Padmasusastra. Triangulation is used to analyze data. The data analysis technique used a content analysis model. The results and conclusions of the study show that through the narrative, storyline, and character characters. Implicitly or explicitly show human politeness attitudes towards all entities. Community politeness in NTKP is displayed through metaphorical language strategies. The metaphor of politeness in NTKP is influenced by the author's socio-cultural conditions as a Javanese who is thick with Orientalist ethical values. Cultural symbols are attributes used for the calculation and interpretation of strategic language choices. An important implication of the research findings is that human awareness to respect existing entities will build strengths that can guide humans to maintain relationships with all elements. Through NTKP, Ki Padmasusastra emphasizes language politeness, ethics, harmonization, and respect for all.
\end{abstract}

Keywords: Language Politics, Metaphors, Javanese Ethics, Novel

\section{INTRODUCTION}

Language, radically, is the element of life that most distinguishes humans from other species. Language is inherent in people's lives and functions as a means of communication [1] - [4]. The use of language that is good and easy for others to understand will impact good communication. In communicating, humans may have mastered the good lexical and grammatical meanings of the language. However, humans can commit several violations of politeness. Therefore, in sharing, humans need the courtesy to get a good response from their said partners. This is important because of politeness. According to Brown [4], it is a matter of considering how others feel about how they should be treated interactional. This is at the same time the moral of the language that must be used [3]. Modesty is feeling-oriented in saying and doing things that are less straightforward or more complicated than when a person does not consider speaking. Modes of being polite may provide a wider range of indirect sources. Someone does not say what it is to the speech partner to communicate to maintain feelings and comfort towards others [5]. As Abbas [6] said, politeness instructs the interaction actors to produce socially harmonious interactions. This arises from the facts [4] that long-term relationships with people can be important in considering their feelings, encouraging expressions of social closeness, caring, and approval. Thus, it can be said that the communication strategy indirectly and circularly is one of the strategies to practice politeness in language.

The indirect strategy model in language style is part of a circular strategy in the concept of metaphorical language [7]. Kittay (1987) says that metaphorical expressions contain symbolic power that can be categorized into a second-level meaning (symbolic power). At the same time, a third layer, namely pragmatics, implies a strategy of politeness. This is inseparable from the basic understanding that metaphorical expressions are linguistic expressions that cannot be interpreted directly from the symbols used. [8]-[12]. Metaphors are formed because there are deviations in meaning from other references [11][13]. On the one hand, this deviation of meaning can 
obscure the importance of speech, but on the other hand, it can help in language politeness. For this reason, it is important to look at politeness strategies through metaphorical language styles. Although basically, politeness [including metaphors] will be based on a certain culture [14].

At least, in the last two decades, the climate of research on metaphors from a cultural perspective has continued to develop. Some scholars prioritize their conceptual and methodological priorities based primarily on specific cultural models. It shows the relationship between conceptual metaphors and cultural models and shows the integrated model's overall applicability [15]. In this case, Forceville (1996) criticized Conceptual Metaphor Theory for focusing too much specifically on language alone and paying less attention to creativity. The semiotics field has proposed an established and productive research direction for examining the metaphorical symbols accompanying speech [17], [18] using the Blending Theory mechanism. However, none of this work has focused primarily on cultural themes as the basis for emerging metaphors.

Meanwhile, empirical studies of politeness have increased the amount of information we have about various social interaction styles. However, the research emphasis on politeness is largely concerned with differences across cultures [1], with little attention paid to the cross-linguistic and cross-cultural similarities that motivated the theory. The researchers were impressed by different cultural views of politeness, friendliness, individuals, and faces by studying specific cultural patterns in language use [1], [19] [50]. However, in his research, Curl \& Drew [20] claims that the emphasis on context about faces is a significant factor in politeness issues in live conversation. As Brown \& Levinson [5] argues, the desire for positive and negative faces is a good way of conceptualizing modesty's universal basis.

For this problem, if politeness is always associated with a person's face or expression, then what if the object of study is a literary text? Because literature builds the principle of circular communication [7]. The communication that is created is between the author and the reader through the media of fictional texts. Through literature, the author communicates in two ways, namely directly (through the narrator's description) and indirectly, namely by implicitly conveying through storylines, dialogue between characters, character characters, etc. For this reason, the principle of politeness in communication systems in literary texts, which has a wealth of metaphors, will, of course, have its character.
In many narrative works, here, we choose to study Javanese novel literature. The consideration is that Java, with a culture of Orientalism, highly upholds the ethics of politeness [3], [22], [23] as it claims Callicott [24] that we need to re-explore the various ethics contained in Eastern wisdom. This is dealing with local knowledge that can build bridges across disciplines. Apart from that, Java is synonymous with a 'disguised' ocean. This means that the Javanese are rarely forthright in expressing something. Indeed, many admit that Javanese language, literature, and culture have a wealth of metaphors [25]-[27], and hence the Javanese language can be said to have cultural arrogance.

In this study, the researcher chose $\mathrm{Ki}$ Padmasusastra's Roman Tetralogy as the study object because it was a major work after the Javanese poet era. Ki Padmasusastra (author) is a great Javanese writer who dominated the entire transition period to the age of modern Javanese literature [28], [29]. He had established contacts with Dutch colony officials. Since then, he has absorbed a lot of European literary scholarship, and he has tried to integrate it with Javanese literature, which was originally in the form of an 'old poetry' song. NTKP was created 23 years. For this reason, the NTKP is considered to have represented a very long generation of Javanese literature. So, it is believed to have represented the socio-cultural Javanese people from various eras and cultures.

\section{MATERIALS AND METHODS}

This research is an attempt to explain the metaphor of politeness in the language in NTKP. This research is an interdisciplinary study on ethics, communication, language, literature, and culture to explore language politeness. Because the study's findings were phenomena that had not been revealed and were not obtained through statistical procedures, the researcher chose to use a qualitative research paradigm [30]-[32]. Qualitative methods are considered suitable for revealing various kinds of information in literary texts that prioritize researchers' interpretations [33]. More than that, qualitative research [30] can also emphasize the views, assumptions, values, beliefs, and ideologies of the individual.

The object of this research is called cyber literature because the data is taken from literature published online on the website https://www.sastra.org, which the Sastra Lestari Foundation manages, Surakarta, Central Java, Indonesia. Sources of research data are four novels by Ki Padmasusastra, which are detailed as follows. 
Table 1. Data on four novels by Ki Padmasusastra

\begin{tabular}{|l|l|c|c|}
\hline No. & \multicolumn{1}{|c|}{ Novel Title } & $\begin{array}{c}\text { Publication } \\
\text { Year }\end{array}$ & $\begin{array}{c}\text { Catalog } \\
\text { Code }\end{array}$ \\
\hline 1. & $\begin{array}{l}\text { Serat Pethikan Saking } \\
\text { Kabar Angin (SPSKA) }\end{array}$ & 1901 & $\begin{array}{c}1901- \\
315, \# 39\end{array}$ \\
\hline 2. & $\begin{array}{l}\text { Serat Rangsang Tuban } \\
\text { (SRT) }\end{array}$ & 1912 & $\begin{array}{c}1912, \\
\# 516\end{array}$ \\
\hline 3. & Serat Prabangkara (SP) & 1921 & $\begin{array}{c}1921, \\
\# 43\end{array}$ \\
\hline 4. & Serat Kandha Bumi (SKB) & 1924 & $\begin{array}{c}1924, \\
\# 112\end{array}$ \\
\hline
\end{tabular}

This research's data are in the form of words, phrases, and sentences that explicitly or implicitly contain metaphorical aspects of language politeness in NTKP. The qualitative data were classified through content analysis techniques based on the main words and themes [38]. The data analysis technique uses a cultural hermeneutic model, an analysis that aims to find various lingual phenomena [text] in human life through understanding and interpretation. [39]. Therefore, content analysis is necessary to seek deeper information to get the best results.

Efforts to reveal the meaning in the NTKP are carried out very carefully by paying attention to symbols, symbols, and categories. The results of data processing were compared and tested with other data sources [40]. To improve our study, we interpreted the mode of cultural symbols in the text. Simultaneously, the researcher searches the relevant academic literature to identify several pertinent narratives.

The steps of the analysis included: 1) collecting data [text] according to the metaphoric category of language politeness; 2) observing and analyzing according to the research problem; 3) interpret and verify data; and 4) conclude.

\section{RESULTS AND DISCUSSION}

As has been agreed by many experts that metaphor is a linguistic expression that cannot be interpreted directly from the symbol used [8], [10], [41], [42]. Metaphors are formed because there are deviations in meaning from other references. Similes can also explain metaphors. Sometimes simile is a figurative language that is different from metaphor, but actually, it is a distinct sub-species of metaphor. [10], [42]. Meanwhile, politeness is a matter of considering other people's feelings about how they should be treated interactional [4]. It is a form of moral language [3] and social ethics [22]. Therefore, the metaphor of politeness, in this case, is a linguistic expression using other references that aim to bring out the effect of politeness.

Based on the analysis that has been done, several things can be captured. The study's results and findings will be described in the deductive form, starting from the presentation of metaphorical forms of linguistic politeness. Then proceed with interpreting the influence of Javanese cultural values on politeness in the literary communication system. Based on the data analysis that has been done, there are several metaphors of politeness that can be captured. There are two metaphors of politeness in NTKP, namely the metaphor of politeness presented in the dialogue between figures and the metaphor of politeness conveyed directly by the author. In turn, each type will be explained as follows.

\subsection{Metaphors of Politeness in Dialogue Between Characters}

This section will provide findings and analysis on the metaphors of politeness associated with intercharacter dialogue. Data on metaphors of this type include: 1) respect, 2) inferiority complex and 3) refining terms through class language, 4) refining terms through proverbs, 5) exalting the dignity of the third person, 6) respecting the environment. The following describes the types, forms, code, sources, and manuscript pages in the form of a summary table.

Table 2. Metaphors in Dialogue Between Characters

\begin{tabular}{|c|l|l|l|}
\hline Kinds of Courtesy & \multicolumn{1}{|c|}{ Metaphorical Forms of Politeness } & Catalog Code & \multicolumn{1}{|c|}{ Novel Title \& Page } \\
\hline Respect & The drawing of a woman is like a flower & MID.01 & SRT/P.53 \\
\hline \multirow{3}{*}{} & The expression of one's intelligence is like the sharpness of a knife & MID.02 & SRT/ P.64; SKB/ P.13 \\
\cline { 2 - 4 } & The analogy of female beauty is like an excess of beauty & MID.03 & SKB/P.27 \\
\cline { 2 - 4 } & Appreciating one's intelligence is like an overload of thoughts & MID.04 & SKB/P.30 \\
\cline { 2 - 4 } & The expression of beauty is like provoking emotion & MID.05 & SKA/P.89-90 \\
\cline { 2 - 4 } & The analogy of female beauty is like the moon & MID.06 & SRT/P.28 \\
\cline { 2 - 4 } & The analogy of female beauty is like a star & MID.07 & SRT/P.33-34 \\
\cline { 2 - 4 } & The likeness of female beauty is like the jewel of the world & $\begin{array}{l}\text { SRT/P.101; SP/P.12; } \\
\text { SKA/P.10 }\end{array}$ \\
\cline { 2 - 4 } & $\begin{array}{l}\text { The analogy of giving someone's knowledge is like having penetrated } \\
\text { himself }\end{array}$ & MID.09 & SRT/P.101 \\
\cline { 2 - 4 } & The analogy of a woman is like a king's sheath & MID.10 & SKB/P.37 \\
\hline
\end{tabular}




\begin{tabular}{|c|c|c|c|}
\hline & King's likeness is godlike & MID.11 & $\begin{array}{l}\text { SKA/P.57; SRT/P.6; } \\
\text { SRT/P.29 }\end{array}$ \\
\hline & The drawing of a king is like the jewel of the world & MID.12 & SKA/P. 35; SKA/P.67 \\
\hline & The Pastor's drawing is like the jewels of the world & MID.13 & SKA/P.10 \\
\hline \multirow{10}{*}{$\begin{array}{l}\text { Inferiority (Degrading } \\
\text { the speaker) }\end{array}$} & The speaker is like a beggar & MID.14 & SRT/P.87 \\
\hline & The speaker is like an oppressed person & MID.15 & SKB/P.30 \\
\hline & The supposition of the speaker's misery in life & MID.16 & SRT/P.93 \\
\hline & The presupposition of the speaker's misery when they want to serve & MID.17 & SP/P.60 \\
\hline & Supposing the speaker's suffering when asking for love & MID.18 & SKA/P.73 \\
\hline & The presumption of the speaker as a traitor & MID.19 & SKA/P.28 \\
\hline & The supposition of speakers as ants in serving the king & MID.20 & SKB/P.16 \\
\hline & Pengandain speaker as an animal when looking for his lover & MID.21 & SKA/P.78 \\
\hline & The raising of the speaker as a tutor & MID.22 & SKA/P.106 \\
\hline & An analogy of a speaker's stupidity is like never going to school & MID.23 & SRT/P.88 \\
\hline \multirow[t]{14}{*}{$\begin{array}{l}\text { Refine terms through } \\
\text { classic language }\end{array}$} & Smoothing sentences about courage & MID.24 & SRT/P.87 \\
\hline & Smoothing sentences about surprise & MID.25 & SKB/P.44 \\
\hline & Smoothing sentences about submission & MID.26 & SKB/P.27; SKB/P.30 \\
\hline & Smooth the term rape & MID.27 & SRT/P.53 \\
\hline & Smooth harsh sentences & MID.28 & SRT/P.88; SP/P.7 \\
\hline & Smoothing the term 'death' & MID.29 & SKB/P.27; SRT/P.103 \\
\hline & Smooth the language of anger & MID.30 & SKA/P.54 \\
\hline & Smooth the term suicide & MID.31 & SKA/P.248 \\
\hline & Refine the term sadness & MID.32 & SKA/P.198 \\
\hline & Refine the term adopted child & MID.33 & SRT/P.93 \\
\hline & Refine the term "convex" & MID.34 & SKA/P.204 \\
\hline & Refine the term "virgin" & MID.35 & SP/P.2 \\
\hline & Smooth out innuendos & MID.36 & SKA/P.97 \\
\hline & Refine the term ugly refugee & MID.37 & SKA/P.33 \\
\hline \multirow[t]{7}{*}{$\begin{array}{l}\text { Smoothing } \\
\text { sentences through } \\
\text { proverbs } \\
\end{array}$} & The proverb about low dignity & MID.38 & SP/P.27-28 \\
\hline & Proverbs about household & MID.39 & SP/P.50 \\
\hline & The proverb of giving up state duties & MID.40 & $\begin{array}{l}\text { SP/P.54; SKB/P.27 } \\
\text { SKB/P.22; SKA/P.191-192; } \\
\text { SKA/P.229; SKA/P.309 }\end{array}$ \\
\hline & The adage about distress & MID.41 & SKB/P.10 \\
\hline & The proverb about the meaning of warrior & MID.42 & SKB/P.24 \\
\hline & The proverb about twins & MID.43 & SKB/P.40 \\
\hline & The proverb about losing the enemy & MID.44 & SKA/P.154-155 \\
\hline $\begin{array}{l}\text { Elevating the dignity } \\
\text { of the 3rd person }\end{array}$ & $\begin{array}{l}\text { The likeness of the royal family is like the offspring of flowers and } \\
\text { seeping, honey }\end{array}$ & MID.45 & SP/P.68 \\
\hline $\begin{array}{l}\text { Respect for the } \\
\text { environment }\end{array}$ & Respect the celestial environment & MID.46 & SP/P.71 \\
\hline
\end{tabular}

Note: MID (in data code) = Metaphors in Inter-Figure Dialogue, $\mathrm{P}$ (in novel's title \& page) = Page

Based on the data, the figures, plots, and social events in NTKP represented society's imagination and conditions at that time. The use of language, both dialogue between characters and narrative language displayed in the story, refers to the author's sociohistorical experience. The NTKP story's contents describe the people who are still very close to Javanese traditional culture, which is thick with ethics. This condition causes the image of politeness to appear stronger.
Many experts say that the Javanese are always seen as having a gentle, refined, polite personality in speech and behaviour [22], [43], [44]. This attitude has become a habit in Javanese socio-cultural life. Javanese culture about this is explained through a storyline about the meeting between Prince Warihkusuma and Dèwi Wrêsti. Even though they are lovers, they prioritize politeness with krama (high level of speech) in speaking. Dèwi Wrêsti felt devastated by the forced marriage carried out by Warihkusuma's older brother, Warsakusuma. Even though he had experienced this brutal treatment, Dèwi 
Wrêsti still tried to use polite language in telling, as well as courteous in using the reference word addressed to Warsakusuma. That matter is illustrated in the MID.01 data in the following text excerpt.

"Because the flower juice that is still budding has been forcibly sucked by the tantrum of the insects" (SRT / $53)$.

From the data above, the flower essence refers to Dèwi Wrêsti as a symbol of women. Then, the insect raging is a representation of Warsakusuma's attitude as the person who raped him. The metaphor in this conversation is that Javanese people still try to be polite to others, even in difficult situations.

Another form of politeness that reflects respect is also reflected in MID.02, MID.03, MID.04 data which likens one's intelligence to the sharpness of a knife, is an effort to respect speech partners, so that speech partners feel more respectable. The data MID.05 MID.06, MID.07, MID.08, MID.09, MID.10, MID.11, MID.12, MID.13 is an effort of politeness to raise the dignity of speech partners by making various flattery. This attitude cannot be separated from Javanese customs; which most Javanese people are eager to be praised. Thus, the speech partner will feel more respected so that communication will continue to run well.

Another politeness that is conveyed through direct speech is in the form of an inferiority complex. This attitude is quite different from the perspective of humility proposed by Brown and Levinson (1987). Maybe this is an exaggeration, but the attitude of inferiority is an attempt to sacrifice his self-esteem to respect the speech partner. An example of this is illustrated via MID data 15.

"I am a descendant of a poor person as well as a pidak padarakan person, it is hoped that this royal retainer will make the world roar ... especially I am expected to become the heirloom of the king" (SKB / 30)

In the data above, the phrase orang pidak padarakan In a separate meaning orang (human) + pidak (stepped on) + padarakan (people), which semantically means the oppressed humans/commoners, which also has the connotation of ignorant people. This expression attempts to undermine the self-esteem of speakers who are too exaggerated because, in reality, the speakers are people of middle dignity who also have the knowledge and supernatural powers. In Javanese conversation, this attitude became a tradition because they humble themselves to a low level. That way, the distance between the speaker's dignity and the speech partner will be further away so that the speech partner's pride will be even greater. Another condescending thing is also reflected in the data MID.16, MID.16, MID.18 through a metaphor describing the speakers' sufferers. This is done to expect a reply from the said partner. Maybe this is a negative behaviour, but in terms of politeness, this is done to elevate the speech partner's dignity so that the speech partner's meaning can be fulfilled.

Other metaphorical forms are also illustrated through the class language represented through data MID.24, MID.25, MID.26, MID.27, MID.28, MID.29, MID.30, MID.31, MID.32, MID. 33, MID.34, MID.35, MID.36, MID.37, which is an expression of politeness of terms about courage, shock, rape, harsh sentences, death, anger, suicide, sadness, adopted child, asking, virgin, innuendo, and do bad things. Then, the metaphor of politeness is also depicted in the form of a proverb representing the meaning of low dignity, having a household, surrendering state duties, distress, the sense of warriors, twins, and losing enemies. Then, in direct conversations between figures, politeness is addressed to speech partners and aims to elevate the second person's dignity, as illustrated in MID data 45. Also included, politeness is addressed to the celestial elements depicted in MID data. 46. This means that, in direct conversations, expressions of politeness are not only managed to second-person speech partners, but politeness is also addressed to third people and even non-humans like MID.46. This means that politeness in Javanese culture respects speech partners and respects all people and objects spoke. This is important because metaphors as an indirect expression are a means to reduce social tension [45].

In turn, the respect or politeness achieved in a more form will become a pragmatic space between the interlocutor and the reference [46]. In this sense, metaphorical strategies can serve as stepping stones to implicatures. Metaphorically, the main communication commitment is found through planting aspects through characterizing the material that is understood. In speaking metaphorically, a speaker does not intend to commit to semantic content because its main purpose is to sharpen the senses of speech.

\subsection{Metaphors of Politeness in the Author's Narrative}

In NTKP, the narrative of politeness is found in direct speech through dialogue between characters and through the author's narrative. In this metaphor of politeness, there are six categories of politeness types, namely 1) Refining language through terms, 2) Refining terms through proverbs, 3) Upholding the dignity of speech partners, 4) Respect, 5) Humility, and 6) Respecting the environment. Data about the types of politeness, metaphorical form, data code, 
novel titles, and pages will be shown in the following table.

Table 3. Metaphors in the Author's Narrative

\begin{tabular}{|c|c|c|c|}
\hline Kinds of Politeness & Metaphorical Forms of Politeness & Catalog Code & Novel Title \& Page \\
\hline \multirow{19}{*}{$\begin{array}{l}\text { Smooth the language } \\
\text { through terms }\end{array}$} & Smooth the term poison & MAN.01 & SRT/P.85 \\
\hline & Refine the term about male helplessness & MAN.02 & SRT/P.86 \\
\hline & Smooth out the term about anxiety & MAN.03 & SRT/P.88 \\
\hline & Refine a term about sadness & MAN.04 & SP/P.14 \\
\hline & Refine the term fear & MAN.05 & SP/P.18 \\
\hline & Refine the term about body blackness & MAN.06 & SP/P.43 \\
\hline & Refine the term fear & MAN.07 & SP/P.56 \\
\hline & Refine a term about anger & MAN.08 & SKA/P.152 \\
\hline & Refine a term about courage & MAN.09 & SKA/P.54 \\
\hline & Refine parental terms & MAN.10 & SRT/P.96 \\
\hline & Smooth out the term thief & MAN.11 & SKA/P.176 \\
\hline & Smooth language is not polite & MAN.12 & SKB/P.27 \\
\hline & Smooths out anger & MAN.13 & $\begin{array}{l}\text { SKA/P.151-152; SKA/P.297; } \\
\text { SKA/P.53 }\end{array}$ \\
\hline & Smooth sadness & MAN.14 & $\begin{array}{l}\text { SKA/P.169; SKA/P.300 SKA/P.310; } \\
\text { SRT/P.49 }\end{array}$ \\
\hline & Smooth the war defeat & MAN.15 & SRT/P.92 \\
\hline & Smooth Death & MAN.16 & SP/P.20; SKB/P.47 \\
\hline & Smoothing out the erotic language & MAN.17 & $\begin{array}{l}\text { SKB/P.40-41; SKA/P.113; } \\
\text { SKA/P.249; SKA/P.298; SKA/P.299; } \\
\text { SKA/P.113; SKA/P.201 }\end{array}$ \\
\hline & Smooth the term rape & MAN.18 & SKA/P.144; SRT/P.53 \\
\hline & Refines the language of war & MAN.19 & SP/P.58 \\
\hline \multirow{10}{*}{$\begin{array}{l}\text { Smooth out terms through } \\
\text { proverbs }\end{array}$} & The proverb about shame & MAN.20 & SKA/P.277 \\
\hline & The proverb about courage & MAN.21 & SKA/P.282 \\
\hline & The proverb about heartbreak & MAN.22 & SKA/P.291, SKA/ P.293 \\
\hline & The proverb about fire & MAN.23 & SRT/P.9 \\
\hline & The proverb about fixation of words & MAN.24 & SRT/P.41 \\
\hline & The proverb about war & MAN.25 & SRT/P.92, SRT/ P.92 \\
\hline & The proverb about twins & MAN.26 & SRT/P.112 \\
\hline & The proverb about losing dignity & MAN.27 & SKA/P.71 \\
\hline & The proverb 'opens disgrace' & MAN.28 & SP/P.63 \\
\hline & The proverb 'looking for trouble & MAN.29 & SP/P.84 \\
\hline \multirow{4}{*}{$\begin{array}{l}\text { Upholding the dignity } 0 \\
\text { speech partners }\end{array}$} & Elevating one's self-image & MAN.30 & SP/P.24 \\
\hline & To elevate one's position & MAN.31 & SP/P.18 \\
\hline & Flatter someone & MAN.32 & SRT/P. 48 \\
\hline & Convey one's strengths & MAN.33 & SKA/P.68-69 \\
\hline \multirow[t]{2}{*}{ Respect } & Human depiction & MAN.34 & $\begin{array}{l}\text { SKB/P.11; SKB/P.34; SKA/P.90; } \\
\text { SKA/P.197; SKA/P.198; SP/P.90; } \\
\text { SKB/P.40; SKB/P.40-41 }\end{array}$ \\
\hline & Respect for the 3rd person & MAN.35 & SRT/P.28; SKA/72; SKB/P.38 \\
\hline Humble & Apologize & MAN.37 & SP/P.17 \\
\hline $\begin{array}{l}\text { Respect for the } \\
\text { environment }\end{array}$ & Respect the mountain & MAN.36 & SKA/P.71; SRT/P.95; SKA/P.18 \\
\hline
\end{tabular}

Note: MID (in data code) = Metaphors in the Author's Narrative, $\mathrm{P}$ (in novel title \& page) = Page

Based on the data in table 3 , the metaphorical character of politeness is a little different compared to table 2. Table 3 shows two types of communication, namely 1) the author immediately says to the reader; 2) the author conveys a message to the reader through the narrative text. The second category is implied messages that readers should analyse themselves.

Metaphors of politeness in this type of communication: As a Javanese, the author conveys 
stories and messages directly to the reader through polite language. This can be seen in the MAN.01 data, which is the story of a male character named Radèn Udakawimba who meets a girl named Rara Sêndhang. At that time, Rara Sêndhang learned to use a 'bra.' Because he was still studying, his bra came off. At the same time, Radèn Udakawimba saw that, and he felt poisoned. The quote below illustrates just that.

'The Prince is like being caught by a bra strap carrying an effective poison; fortunately, he can still see the footsteps and see the light after lifting the strap' (SRT / P.85)

In this quote, the metaphor of politeness is seen in the word 'panacea.' In this context, the poison in question is not real poison because when viewed from its semantic meaning, what is carried in the bra is the breast. In this case, breasts are connoted with efficacious poison because women's breasts can ignore consciousness for men. The author uses metaphors in MAN.01 data to smooth the speech, not to appear obscure.

Furthermore, an attempt to refine the term is seen in the MAN.02-MAN.19 data describes male helplessness, restlessness, sadness, fear, the blackness of the body, anger, thieves, war defeat, death, erotic language, rape, and war. When viewed from the type, these words are words with negative connotations, likewise in the second type of politeness category, namely the use of proverbs. This category is shown in the MAN.20-MAN.29 data. In this case, proverbs' service aims to describe things about shame, courage, heartbreak, fire, clinging to words, war, loss of dignity, exposing disgrace, and looking for trouble. The application of terms and sayings in this category is a form of metaphor used to smooth out negative, impolite, and even harsh words.

In the next type of sarcasm, the categories found were respect for the speech partner's dignity, respect, humility, and respect for the environment. This is displayed on the MAN.30-MAN.30 record. Based on these data, it means that, in establishing communication with speech partners, the author still uses characters similar to the direct speech model as illustrated in the analysis of points (1). This reinforces the belief that the author, as a Javanese, continues to uphold politeness in delivering communication messages, either directly or indirectly. The author practices the flow of communication through a circular path in the form of a metaphor in this case, as an effort to maintain and simultaneously provide moral, ethical, and politeness teaching through literary works.

In this case, the Javanese culture in NTKP displays norms and values that influence politeness, and a person tends to be more courteous to all entities. It aims to achieve stable social relationships that can differentiate certain social groups. Different ethnic groups of people may tend to embody certain metaphors in certain ethnocentric aspects [47]. Thus, culture provides evidence that language use occurs naturally, showing how modesty is interactively modulated with local social factors in the community. Although this cannot be separated from the notion that cultural cognition distributed across minds in cultural groups plays a key role as a source of identity and metaphorical variation. [48], [49]. Thus, NTKP, in this case, is trying to create a metaphor built from the conventional metaphorical structure of the local community from everyday culture.

\section{CONCLUSION}

NTKP is a reflection of the universality of Javanese literature wrapped in language aesthetics. Through the storyline and character characters, implicitly or explicitly shows a sense of ethics towards all elements, which is oriented towards harmonizing relations between humans and their environment, both the social and natural environment. The image of community life is the goal of an ideal standard of living in accordance with the values that developed in Javanese culture at the time the NTKP was created.

Socio-culturally, the Javanese in NTKP, tend to be polite. This is represented in two categories: (1) Javanese people in NTKP tend to have politeness towards all speech partners, both familiar and unfamiliar; (2) Javanese people in NTKP tend to choose to use metaphorical language style as a politeness strategy. For this reason, politeness in metaphors is marked by the use of cultural symbols in groups to avoid disputes. Politeness is used to guard feelings by expressing indirect speech acts. All of this defines the meaning of the specific communicative expression in a way that deviates from direct communication. Holistically, the politeness of language in NTKP is influenced by the author's sociocultural conditions as a Javanese who is thick with Orientalist ethical values.

The claim, then, is that the types of cultural symbols for social relations underlying societies are human attributes and socio-cultural dimensions that universally fit into the calculation and interpretation of strategic language choice. For this reason, one can obtain the choice of linguistic realization from the practical metaphorical strategy of politeness. Thus, through a metaphorical language style strategy, humans can apply polite language to reflect human intentions to build a common foundation and 
ultimately achieve and maintain friendly and harmonious relationships with all entities.

The important implication of the findings is that human awareness to respect each other existing entities will build strength that can guide humans to seek fellowship with other humans and their environment. Through NTKP, Ki Padmasusastra emphasizes language politeness, social and environmental ethics, harmonization, and respect for all. Thus, NTKP engages in language politeness in three ways: social ethics, scientific, intellectual, and practical.

\section{AUTHORS' CONTRIBUTIONS}

All authors have the same contribution to this study.

\section{ACKNOWLEDGMENTS}

We thank the LPDP for funding this research. Acknowledgements and appreciation to University Centre of Excellence Javanologi for Javanese Traditions Universitas Sebelas Maret

\section{REFERENCES}

[1] Y. Huang, "Politeness Principle in Cross-Culture Communication," English Lang. Teach., vol. 1, no. 1, pp. 96-101, 2008, doi:10.5539/elt.v1n1p96.

[2] J.D. Picken, "Literature, Metaphor and the Foreign Language Learner," Lit. Metaphor Foreign Lang. Learn., pp. 1-174, 2007, doi: $10.1057 / 9780230591608$.

[3] S.T. Widodo, "Language Morality," vol. 280, no. Basa, pp. 15-18, 2018.

[4] P. Brown, Politeness and Language, Second Edi., vol. 18. Elsevier, 2015.

[5] P. Brown and S. C. Levinson, Politeness: Some Universals in Language Usage. Chambridge: Cambridge University Press, 1987.

[6] N.F. Abbas, "Positive politeness \& social harmony in literary discourse," Int. J. Appl. Linguist. English Lit., vol. 2, no. 3, pp. 186-195, 2013, doi: 10.7575/aiac.ijalel.v.2n.3p.186.

[7] T. Widijanto, Metafora Waktu: Kumpulan Esai Budaya. Sidoharjo: Tankali, 2017.

[8] E.F. Kittay, Metaphor: Its Cognitive Force and Linguistic Structure. Oxford: Clarendon Press, 1987.

[9] F. MacArthur, "Kövecses, Z. (2010). Metaphor:
A Practical Introduction," Metaphor Soc. World, vol. 1, no. 1, pp. 113-118, 2011, doi: 10.1075/msw.1.1.10mac.

[10] L.D. Ritchie, Metaphor. 2011.

[11] P. Wolf, "Epilepsy and metaphors in literature," Epilepsy Behav., vol. 57, pp. 243-246, 2016, doi: 10.1016/j.yebeh.2015.12.029.

[12] G. Lakoff and M. Johnson, "Conceptual Metaphor in Everyday Language," J. Philos., vol. 77, no. 8, pp. 453-486, 1980.

[13] F. Safarnejad, I. Ho-Abdullah, and N. M. Awal, "Patterns of translation of sadness metaphors from Persian into english: A cognitive analysis," Pertanika J. Soc. Sci. Humanit., vol. 26, no. 4, pp. 2417-2434, 2018.

[14] Pranowo, Berbahasa secara santun. Yogyakarta: Pustaka Pelajar, 2009.

[15] E. Panahbar, A. Hesabi, and H. Pirnajmuddin, "Aesthetics in the relationship of conceptual metaphors and cultural models in the translation of Rubayyat of Khayyam," 3 L Lang. Linguist. Lit., vol. 22, no. 3, pp. 49-63, 2016, doi: 10.17576/3L-2016-2203-04.

[16] C. Forceville, Pictorial metaphor in advertising. New York: Psychology Press, 1996.

[17] C. Müller, Metaphors dead and alive, sleeping and waking: A dynamic view. Chicago: University of Chicago Press, 2009.

[18] C. Müller, A. Cienki, E. Fricke, S. Ladewig, D. McNeill, and S. Tessendorf, Body-languagecommunication, vol. 1. Berlin: Walter de Gruyter, 2013.

[19] H. Spencer-Oatey and D. Z. Kádár, "The Bases of (Im)politeness Evaluations: Culture, the moral order and the East-West divide," East Asian Pragmat., vol. 1, no. 1, 2015, doi: 10.1558/eap.v1i1.27762.

[20] T.S. Curl and P. Drew, Contingency and action: A comparison of two forms of requesting, vol. 41, no. 2. 2008

[21] P. Brown and S. C. Levinson, Politeness: Some Universals in Language Usage. Chambridge: Cambridge University Press, 1987.

[22] F. Magnis-Suseno, Etika Jawa. Jakarta: PT Gramedia, 1984

[23] O.Y. Pamungkas, "Environmental Wisdom: An Observation of Ecocriticism towards the 
Javanese Cyber Literature in 20 TH Century," vol. 28, no. 10, pp. 46-60, 2019.

[24] J.B. Callicott, Menuju Suatu Etika Lingkungan. Yogyakarta: Kanisius, 2003.

[25] Nurnaningsih, "The Metaphors of Sexual Organs, Sexual Activities, and Sexual Activities' Impacts in Serat Centhini, Written By Pakubuwana V Nurnaningsih," Int. J. Lang. Linguist., vol. 2, no. 5, pp. 214-222, 2015.

[26] E. Rahardian and D. Nirmala, "The Force Scheme in Javanese Emotion Metaphors," Parol. J. Linguist. Educ., vol. 8, no. 1, p. 12, 2018, doi: 10.14710/parole. v8i1.12-18.

[27] I. Solikhah, "Metaphors in Javanese Mantra of Kiyai Pradah Ritual Ceremony," J. Chem. Inf. Model., vol. 53, no. 9, pp. 127-142, 2013.

[28] J.J. Rass, Masyarakat dan Kesusastraan di Jawa. Jakarta: Yayasan Pustaka Obor Indonesia, 2014.

[29] G. Quinn, "Padmasusastra' s Rangsang Tuban : A Javanese Kabatinan Novel Padmasusastra 's Rangsang Tuban : A Javanese Kabatinan Novel," no. September, 1982, doi: 10.3406/arch.1982.1777.

[30] K. Charmaz, "Grounded Theory pada Abad XXI: Aplikasinya dalam Memajukan Penelitian Keadilan Sosial," in The Sage Handbook of Qualitative Research, Edisi keti., N. K. D. dan Y. S. Lincoln, Ed. Yogyakarta: Pustaka Pelajar, 2011, pp. 547-580.

[31] A. Strauss and J. Corbin, Dasar-Dasar Penelitian Kualitatif. Yogyakarta: Pustaka Pelajar, 2010.

[32] S.W. Vanderstoep and D.D. Johnston, "Research Methods for Everyday Life (Blending Qualitative and Quantitative Approaches)," p. 400, 2008.

[33] I.N.K. Ratna, Metodologi Penelitian Kajian Budaya dan Ilmu Sosial Humaniora pada Umumnya. Yogyakarta: Pustaka Pelajar, 2010.

[34] K. Padmasusastra, Serat Pêthikan Saking Kabar Angin. Surakarta: Yayasan Sastra Lestari, 1901.

[35] K. Padmasusastra, Serat Rangsang Tuban. Surakarta: Yayasan Sastra Lestari, 1912.

[36] K. Padmasusastra, Serat Prabangkara. Surakarta: Yayasan Sastra Lestari, 1921.

[37] K. Padmasusastra, Serat Kôndha Bumi. Surakarta: Yayasan Sastra Lestari, 1924.
[38] K. Krippendorff, "Validity in Content Analysis," Comput. fÃ̄l/4r die Kommun., pp. 69-112, 1980, [Online]. Available: http://repository.upenn.edu/asc_papers/291.

[39] S.T. Widodo, Etnolinguistik: Paradigma, Metode, dan Teori Penunjang. Surakarta: UNS Press, 2015.

[40] H.B. Sutopo, Metode Penelitian kualitatif. Surakarta: Sebelas Maret University Press, 2002.

[41] G. Lakoff et al., A cognitive theory of metaphor, vol. 2, no. 3. 2005.

[42] E. Sommer and D. Weiss, "Metaphors dictionary," Vasa, 2001, [Online]. Available: http://medcontent.metapress.com/

[43] C. Geertz, Agama Jawa: Abangan, Santri, Priyayi. Depok: Komunitas Bambu, 2013.

[44] N. Mulder, Mistisisme Jawa. Yogyakarta: LKiS, 2001.

[45] S.G. Obeng, "Language and polotics: indirectness in political discourse." SAGE Publication, London, 1997.

[46] M.K. Hiraga, "Metaphor and Iconicity," 2005, doi: $10.1057 / 9780230510708$.

[47] Z. Kovecses, Metaphor in Culture: Universality and Variation. New York: Oxford University Press, 2005.

[48] Z. Khajeh and Imran-Ho-Abdullah, "Persian Culinary Metaphors: A Cross-cultural Conceptualization," vol. 12, no. January, pp. 6987, 2012.

[49] Z. Sohrabi and H. Pirnajmuddin, "John Donne's metaphors of self and empire: A cognitive analysis," 3 L Lang. Linguist. Lit., vol. 23, no. 2, pp. 14-26, 2017, doi: 10.17576/3L-2017-230202.

[50] Djatmika, Wibowo, A.H. Kusuma, D.I. B Mohamad, B. Lexical Choices as the Representation of Convenience Shifting from Mother Tongue to Second Language. Advanced Science Letters 22 (12), 4397-4400. 2016 